\title{
Psikolojik Danışman Adaylarının Empatik Eğilim, Utangaçlık, Olumsuz Değerlendirilme Korkusu ve Sosyal Beceri Düzeylerinin Farklı Değişkenler Açısından İncelenmesi
}

\author{
An Investigation of Counselor Candidates' Empathic Tendency, Shyness, Fear \\ of Negative Evaluation and Social Skills in Relation to Varied Variables
}

\section{Evrim ÇETINKAYA YILDIZ* Emre TOPRAK **}

\begin{abstract}
$\ddot{\boldsymbol{O}}_{z:} \mathrm{Bu}$ araştırmanın amacı Erciyes Üniversitesi Rehberlik ve Psikolojik Danışmanlık (RPD) lisans programı öğrencilerinin empatik eğilim, utangaçlık, olumsuz değerlendirilme korkusu ve sosyal beceri düzeylerinin cinsiyet, sınıf, aylık harçlık, yaşamın çoğunun geçtiği yer ve STK üyelik durumu değişkenlerine göre farklılaşma düzeylerini incelemektir. Araştırmanın çalışma grubu 2014-2015 akademik yılında Erciyes Üniversitesi Eğitim Fakültesi'nin RPD programında öğrenim gören 87'si erkek (\%24.6), 267'si kadın (\%75.4) toplam 354 öğrenciden oluşmaktadır. Veri toplama aracı olarak kişisel bilgi formu, Empatik Eğilim Ölçeği, Utangaçlık Ölçeği, Olumsuz Değerlendirilme Korkusu Ölçeği ve Sosyal Beceri Ölçeği kullanılmıştır. Sonuçlar şunları göstermektedir; erkek öğrencilerin empatik eğilim düzeyleri kadın öğrencilerin empatik eğilim düzeylerinden anlamlı düzeyde düşüktür. RPD öğrencilerinin empatik eğilim ve sosyal beceri düzeyleri arasında sınıflarına göre anlamlı bir farklılık bulunamamıştır. Utangaçlık değişkeni ile ilgili bulgular incelendiğinde 4. sınıftaki öğrencilerin utangaçlık düzeylerinin, 1. ve 2. sınıfta öğrenim gören öğrencilerin utangaçlık düzeylerinden anlamlı düzeyde düşük olduğu gözlenmektedir. Olumsuz değerlendirilme korkusu değişkeni ele alındığında ise, 1. sınıftaki öğrencilerin olumsuz değerlendirilme korkusu düzeyleri, 3. sınıfta öğrenim gören öğrencilerin olumsuz değerlendirilme korkusu düzeylerinden anlamlı düzeyde yüksek bulunmuştur.
\end{abstract}

Anahtar sözcükler: RPD öğrencileri, Empatik Eğilim, Utangaçlık, Olumsuz Değerlendirilme Korkusu

\begin{abstract}
The purpose of this study was to investigate the empathic tendency, the shyness, the fear of negative evaluation, and the social skills of Erciyes University Psychological Counseling and Guidance students in relation to gender, grade, monthly income, the place where they spend most of their life and NGO membership variables. The participants in this research were 354 volunteers $(24.6 \%$ male, $75.4 \%$ female) enrolled in the ERU Psychological Counseling program in the 2014-2015 academic year. The data collection instruments were the demographic form, the Empathic Tendency Scale, the Shyness Scale, the Fear of Negative Evaluation Scale, and the Social Skills Scale. The results show the empathic tendency level of male students was significantly lower than the female students. In respect to the empathic tendency level and social skills, no significant difference was found between different grade levels. The findings concerning shyness, show the shyness levels of $4^{\text {th }}$ grade students was significantly lower than that of $1^{\text {st }}$ and $2^{\text {nd }}$ grade students. Concerning of fear of negative evealuation, the $1^{\text {st }}$ grade students' fear of negative evaluation level was found to be significantly higher than $3^{\text {rd }}$ grade students.
\end{abstract}

Keywords: Psychological Counseling Students, Empathic Tendency, Shyness, Fear of Negative Evaluation

\footnotetext{
* Yrd. Doç. Dr., Erciyes Üniversitesi, Eğitim Fakültesi, Eğitim Bilimleri Bölümü, Kayseri. evrim@erciyes.edu.tr

** Arş. Gör., Erciyes Üniversitesi, Eğitim Fakültesi, Eğitim Bilimleri Bölümü, Kayseri. etoprak@erciyes.edu.tr Bu çalışma 13. Ulusal Psikolojik Danışma ve Rehberlik Kongresinde sözel bildiri olarak sunulmuştur.
} 


\section{Giriş}

Psikolojik danışma süreci danışan ile danışman arasında geçen etkileşimsel bir süreçtir. Psikolojik danışmanlar aldıkları eğitim ile bazı teorileri, modelleri ve becerileri öğrenir ve bunlarda yetkinleşirler daha sonra ise bu öğrendiklerini danışanın sürece getirdiği problemlere/durumlara uygularlar. Kısacası, psikolojik danışma alanı karmaşık süreçleri olan ve beceri gerektiren bir hizmet alanıdır (Schmidt 2004). İyi bir yardım ilişkisi için psikolojik danışmanlar danışanlarının problemlerini iyi dinleyebilmeli, anlayabilmeli, netleştirmeli ve çözüm yolları bulabilmelidirler. Ancak şu bir gerçektir ki, psikolojik danışmanlar yardım sürecine kişilikleri, inançları, dünyaya dönük varsayımları, değer yargıları, tecrübeleri, kültürel ve demografik özellikleriyle kendilerine has bir biçimde dahil olurlar (Hill \& O'Brien 1999) ve bu durum psikolojik danışmanların iletişim kurmaya engel olan bazı kişilik özelliklerinin ya da beceri yetersizliklerinin süreci olumsuz etkilemesine sebep olabilmektedir. Bu sebepledir ki, Türkiye'de ve dünyada psikolojik danışma programlarının en temel hedeflerinden biri öğrencilerde önce iletişim engellerinin ortadan kaldırılması daha sonra ise iletişim becerilerinin ve psikolojik danışma becerilerinin geliştirilmesidir.

Etkili psikolojik danışmanların kişilik özelliklerine dair yapılan ilk araştırmalarda genel olarak açık fikirli olmak, bilişsel esneklik, duyguları anlayabilmek, duygularla ilgili olarak iletişim kurmaya istekli olmak ve yüksek öz sayg1 (Eysenck 1952; Allen 1967; Sprinthall, Whiteley \& Mosher 1966) gibi özellikler yer alır. Daha güncel bir araştırmada ise Corey (2008) psikolojik danışmanlık mesleğini etkili bir şekilde yapabilmek için şu özelliklerin bulunması gerektiğini belirtir; otantik olmak, içten olmak, samimi olmak, anı yaşayabilmek, kendine saygı duymak, kendi olmaktan hoşlanmak, kendi gücünü tanımak ve kabul etmek, değişime açık olmak, yaşama bağlı olmak, yaşamını değiştirecek tercihler yapabilmek, yaptığı yanlışı itiraf etmekten çekinmemek, diğerlerinin mutluluğu ile ilgilenmek vb.

Empati, bir başkasının gözüyle dünyaya bakabilme yeteneğidir ve psikolojik danışmanlık becerileri içinde belki de en önemlisidir (Miville et al. 2006). Dökmen (1994) empatiyi, empatik eğilim (EE) ve empatik beceri (EB) olmak üzere iki yönüyle tanımlar. Empatik eğilim, empatinin duygusal boyutunu oluşturmakta ve bireyin empati yapma potansiyelini göstermektedir. Empati, danışmanın terapötik olarak duruşunu güçlendirir ve süreç içerisinde kişinin kendisini kaybetmekten korkmasına izin vermeden danışan danışman ilişkisini derinleştirir (Pence, 1983). Empatinin öğretilebilir bir kavram olup olmadığı da tartışma konusudur. Örneğin; Rogers ilk çalışmalarında (Rogers 1951) empatinin öğretilebilen bir beceri olduğunu savunur; ancak daha sonraki çalışmalarında (Rogers 1975) empatiyi bir beceri değil, bir var olma şekli olarak tanımlar. Bazı felsefeciler de (örn. Stein 1970) empatinin öğretilemez bir kavram olduğunu savunurlar.

Empati bazı aşamalardan oluşur. Barrett-Lennard (1993) empati sürecinin dört aşamada gerçekleştiğini belirtir; 1) bireyin duygularını fark etmesi ve anlaması 2) iletişim kurması 3) bireyin dinlendiğini ve anlaşıldığını hissetmesi ve 4) bireyin kendini ifade etmesidir. Carkhuff (1969) ise geliştirdiği teoride empatinin bir beceri olduğundan ve empatik becerilerin doğruluk bakımından beşli bir dereceleme ile değerlendirilebileceğinden söz eder. Ancak empati her ne şekilde açıklanırsa açıklansın, Pişkin'in (1989) de belirttiği üzere empatik yönden gelişmiş bir bireyin kişilerarası iletişimde başarılı, empatik yönü zayıf olan bir bireyin ise kişilerarası iletişimde başarısız olması ihtimalinin daha yüksek olacağı alan yazında üzerinde fikir birliğine varılmış bir husustur. Yukarıdaki bahsi geçen etkili psikolojik danışman özellikleri içerisinde yer alan empatik eğilimin psikolojik danışma eğitimi sırasında alınan çeşitli teorik ve uygulamalı dersler ve öğrencilerin kendilerini geliştirmeleri sayesinde arttırılmasının psikolojik danışmanların danışanlarının sorunlarını daha iyi anlayabilmelerine olanak sağlayacağı düşünülür. 
Sosyal beceriler (olumlu-olumsuz duyguları anlatabilme, kişisel haklarını savunabilme, gerektiğinde başkalarından yardım isteyebilme, kendisine uygun olmayan istekleri geri çevirme vb.) kişilerin başkaları ile olumlu etkileşimi başlatmaları ve sürdürmeleri için önemli davranış öğeleridir. Sosyal yeterlik ise, bu davranış öğelerinin sosyal etkileşimini sağlamak amacıyla yeri geldiğinde bir düzen içerisinde kullanılması anlamına gelir (Riggio 1986). Ayrıca Riggio, Tucker ve Coffaro (1989) empati-sosyal beceri ilişkisi için, empatiyi temel sosyal becerilerin tam bir birleşimi gibi görmenin verimli bir alternatif yaklaşım olabileceği şeklinde bir açıklama yapmışlardır. Kişilerarası ilişkiler bağlamında etkili bir iletişim kurabilmek psikolojik danışmanlık gibi mesleklerde oldukça büyük bir önem taşır. Dolayısıyla psikolojik danışmanların pek çok farklı şekildeki sosyal becerilere hakim olmaları ve sosyal etkileşim içerisindeki kendi etkilerinden haberdar olmaları beklenir. Sosyal becerilerin geliştirilmesi psikolojik danışmanların kendilerine daha çok güvenmelerini sağlayacağından danışanlarıyla daha kolay iletişim kurabilecekleri düşünülür ve bu nedenle psikolojik danışman eğitimi için önemli konulardan biri olarak görülür.

Kayg1, kendinden şüphe etme, ön yargı ve düşük öz güven kişinin ilgisini kendisine yöneltmesine neden olur ve bir başkası için terapötik bir var olma durumu yaratmayı zorlaştırır ve dolayısıyla empatinin gerçekleşmesini de engeller (Davis 1990). Nitekim bu tür kaygı ve korkular insanları ilişki kurmaktan alıkoyar. Utangaçlık ve olumsuz değerlendirilme korkusu gibi psikolojik danışman adaylarının ilerideki mesleki kariyerlerini olumsuz etkileyecek bazı sosyal kaygı temelli kişilik örüntülerinin de psikolojik danışma eğitimi sırasında alınan dersler ve kazanılan beceriler sayesinde azalması beklenir.

Utangaçlık, genellikle kaygı ve sosyal durumlardan kaçış duygularının günlük dildeki karş1lığıdır ve oldukça yaygın bir deneyimdir. Utangaç kişilerin başkaları ile birlikteyken kaygı yaşadıkları, çekingen davrandıkları, kendileriyle çok meşgul oldukları ve az konuştukları gözlenir (Briggs 1988). Utangaçlığ 1 tetikleyen durumlar incelendiğinde, yabanc1larla iletişimin, özellikle de karşı cinsle ya da otoriteyi temsil eden kişilerle olan iletişimin, atılgan davranış gerektiren durumların ya da iş görüşmesi gibi değerlendirme içeren durumların öne çıktığı görülmektedir (Russell, Cutrona \& Jones 1986; Watson \& Cheek 1986). Utangaç bireyler, sosyal durumlarda rahatsızlık duyar ve bu durum zamanla çekingenlik, yalnızlık ve depresyon gibi ciddi sorunlar dönüşebilmektedir (Dill \& Anderson 1999). Ayrıca utangaçlığın sadece sosyal alanlarda değil, kişisel, duygusal ve mesleki alanlarda da çeşitli sıkıntılar yarattığı bilinen bir durumdur (Bruch et al. 1997). Jacobs (1996), psikolojik danışmanların utanç yaşayan danışanlarla başarılı bir şekilde çalışabilmeleri için kendilerinin utanç konusunu tolere edebilmeleri ve utanca dayanıklı olmalarının gerekliliğinin üzerinde durmuştur. Kaufman (1993) ise, psikolojik danışmanların kendi utanç süreçlerini anlamaları bunu aşmaları için üç temel nedenin olduğunu öne sürer: 1) Danışman, kendi utanç sürecini tolere etme ve yönetme yeteneğini sergileyerek danışanına model olmalıdır 2) Danışman kendi utanç sürecinden habersiz ise, utancın ele alınmama potansiyelini artırır ve danışanın yaşamında daha önce yer almış olan utanç örüntüleri danışma ilişkisi içinde de tekrar yaşanır 3) Danışmanlar danışanlarını, ancak kendi gidebildikleri yere kadar götürebilirler.

Olumsuz değerlendirilme korkusu yaşayan kişiler, diğer insanların kendilerini eleştirmesinden ya da değerlendirmesinden yana yüksek kaygı duyarlar, yani diğer insanların onlar hakkındaki düşüncelerini çok fazla önemserler. Yapılan çalışmalar da utangaçlığın olumsuz değerlendirilme korkusu ile olan olumlu ilişkisini ve utangaçlığın bu değişken tarafindan anlamlı bir şekilde yordandığını gösterir (Beck, Emery \& Greenberg 1985; Cowden 2005). Utangaç kişilerin başkalarının duygusal ifadelerini olumsuz olarak algıladıkları, sosyal kaygı yaratıcı durumlarda diğer insanların kendilerini daha olumsuz olarak değerlendireceklerini düşündükleri ve 
çevrede bıraktıkları izlenimlerle ilgili olarak daha önyargılı düşüncelere sahip oldukları bulunmuştur. Bu temel korkuyu yaşayan psikolojik danışmanların karşısındaki kişi ile doğal bir iletişim kuramayacağı için gerçek bir terapötik ilişkinin kurulmasından bahsetmenin pek mümkün olmayacağ 1 söylenebilir.

Ulusal Mesleki Bilgi Sisteminde (2012) psikolojik danışma alanına hangi kişilerin daha uygun olacağına dair yer alan açıklamada; akademik olarak başarılı olmak, psikolojiye ilgili olmak, kişilerarası ilişkilerde başarılı olmak, diğer insanları dinlemekten hoşlanmak, onlara yardım etmeyi sevmek, dışa dönük, girişken, sabırlı, empatik becerisi yüksek ve sosyal konulara duyarlı olmak gibi özelliklerin bulunduğu görülür. Bilindiği üzere RPD programlarına sadece akademik mahiyette değerlendirme yapan YGS/LYS gibi merkezi sınavlarla öğrenci alınmaktadır. Fakat yine bilinmektedir ki, Türkiye'nin yaşam koşulları ve mevcut sınav sistemi öğrencilerin kendi kişilik özelliklerine ya da isteklerine göre bağımsız mesleki tercih yapmalarını destekler nitelikte değildir. RPD programını kazanıp kayıt yaptıran öğrencilerin azımsanmayacak bir kısmı da ya ileride devlet memurluğuna atanma ihtimali fazla olduğundan ya da puanı bu programa yettiği için RPD programını tercih etmektedir.

Hali hazırda Türkiye'de yürürlükte olan RPD lisans programının içeriği 1995 yılından itibaren alandaki akademisyenler tarafından tartışılmaya başlanmıştır. Hatta Anabilim Dalı Başkanları toplantılarında üzerinde çalışılmış ve ortak yeni RPD programı üniversitelerde aşamalı olarak uygulamaya geçirilecekken YÖK tarafından Eğitim Fakültelerindeki reform çalışmaları başlatılmış ve RPD programları da diğer öğretmenlik programları ile benzer şablon içinde değerlendirilmiştir (Yeşilyaprak 2009). Doğan'ın (2016, 2) RPD Lisans Programı'nın güncellenmesine ilişkin olarak diğer RPD Anabilim Dalları ile paylaştığı Ege Üniversitesi RPD Anabilim Dalı'nın görüşlerini içeren mektupta da belirtildiği üzere:

“... Halen yürürlükte olan RPD lisans programı düzenlenirken, Psikolojik Danışma ve Rehberlik Yeterlik Alanları yerine Öğretmenlik Yeterlik Alanlar esas alınmıştır. Oysa ne dünyada, ne de Türkiye'de RPD Lisans Programı ögretmen yetiştirmeyi amaçlamaktadır. Elbette, eğitim kurum/kuruluşlarında çalışan psikolojik danışman, bazı işlevleri gerçekleştirirken eğitimci rolü üstlenir. Fakat psikolojik danışmanın, ĕgitimci rolü üstlenmesi nedeniyle RPD Lisans Programı'nın bir öğretmenlik programı olarak değerlendirilmesinin bilimsel bir dayanağ bulunmamaktadır. Çünkü Psikolojik Danışma ve Rehberlik, danışanların kişisel, sosyal, eğitimsel ve mesleki alanlarda gelişmelerini; bu alanlarda karşılaş̧ıkları sorunlarla başa çıkabilmelerini ve yaşamlarını daha fazla doyum alarak sürdürmelerini amaçlayan profesyonel bir yardımdır. Bu nedenle, Psikolojik Danışma ve Rehberlik Yeterlik Alanları (insan gelişimi/psikolojik temeller; sosyal kültürel temeller; eğitimsel temeller; yardım becerileri; grupla çalışma becerileri; mesleki gelişim; bireyi tanıma ve değerlendirme; istatistik, araştırma ve program değerlendirme; mesleki kimlik), Öğretmenlik Yeterlik Alanlarından (alan bilgisi ve becerileri; öğretmenlik meslek bilgisi ve becerileri; genel kültür) farklıdır...".

Mevcut programda yer alan uygulamalı dersler sayıca yetersiz olmakla birlikte (insan ilişkileri ve iletişim, okullarda gözlem, bireysel psikolojik danışma uygulaması, grupla psikolojik danışma uygulaması, mesleki rehberlik uygulaması, alan çalışması ve kurum deneyimi) psikolojik danışman adaylarının hem mesleki hem de kişisel gelişimleri için oldukça faydalı derslerdir; 
ancak bu dersler sınıf mevcudu, fiziksel yetersizlikler, süpervizyon verecek olan öğretim elemanı azlığı ve uygulama etkinliklerinde kullanılabilecek kaynakların (eğitim videoları vb.) yetersiz olması gibi bazı sebeplerle ülkemizdeki üniversitelerin önemli bir kısmında layıkıyla yürütülememektedir. Bu derslerin çoğu, pek çok üniversitede yeterince uygulama yapılmadan ağırlıkla teorik düzeyde işlenmektedir. Hâlbuki psikolojik danışma ve rehberlik mesleğini yürütebilmek için danışmanların öncelikle kendilerinin bireysel ya da grupla psikolojik danışma sürecinden geçmeleri neredeyse bütün psikolojik danışma kuramlarının üzerinde önemle durdukları bir tavsiye hatta gerekliliktir. Bu durum mesleki yetersizliklere ek olarak psikolojik danışman adaylarının kendi kişisel gelişimlerini de tamamlayamadan alandan mezun olmalarına neden olmaktadır. Kısacası, RPD Lisans Programının içeriği ülkemizdeki ihtiyaçları daha iyi karşılayacak şekilde ve uluslararası akreditasyon gereksinimlerine göre yeniden ele alınmalı ve psikolojik danışmanların belirli bir standartta teorik ve uygulamalı eğitim alarak programlardan mezun olmaları sağlanmalıdır.

Türkiye'de bu konuda yürütülen çalışmalar incelendiğinde, mevcut RPD programlarını tercih eden öğrencilerin mesleğe uygun kişilik özelliklerine ve sosyal becerilere ne kadar sahip olarak programa geldikleri, süreç içerisinde kendilerini ne derece geliştirdikleri ve bu kişilik özelliklerinin ve sosyal becerilerin sınıfa, cinsiyete ve başka bazı değişkenlere göre nasıl değiştiği çokça araştırılmış bir konu olmadığı ortaya çıkmaktadır. Bu eksiklikten yola çıkarak bu çalışmanın amacı; Erciyes Üniversitesi RPD lisans programı öğrencilerinin empatik eğilim, utangaçlık, olumsuz değerlendirilme korkusu ve sosyal beceri düzeylerinin cinsiyet, sınıf, aylık harçlık, yaşamın çoğunun geçtiği yer ve STK üyelik durumu değişkenlerine göre farklılaşma düzeylerini incelemektir. Bu araştırma birinci sınıf öğrencilerinin belirlenen değiş̧kenlere yönelik durumunun boylamsal olarak belirlenmesine yönelik planlanmış bir ön çalışmadır. Burada tüm sınıf düzeyleriyle çalışılmış ilk dalga verileri yer almaktadır. Gelecek üç yıllık eğitim döneminin her mayıs ayında bu araştırmadaki birinci sınıf öğrencilerinin belirlenen değişkenlere yönelik düzeyi ölçülecek ve RPD lisans programının bu değişkenler üzerindeki etkisi boylamsal düzeyde tartışılmaya çalışılacaktır.

\section{Yöntem}

\section{Araştırmanın Deseni}

Genel tarama modelinde yürütülen bu araştırmada Erciyes Üniversitesi Eğitim Fakültesinde öğrenim gören RPD öğrencilerinden bir kesit alınarak, bu öğrencilerin empatik eğilim, utangaçlık, olumsuz değerlendirilme korkusu ve sosyal beceri düzeyleri farklı değişkenler açısından incelenmiştir.

\section{Araştırma Grubu}

Araştırmanın çalı̧̧ma grubu 2014-2015 eğitim-öğretim yılında Erciyes Üniversitesi Eğitim Fakültesi'nin RPD programında öğrenim gören 87'si erkek $(\% 24,6), 267$ 'si kadın $(\% 75,4)$ toplam 354 öğrenciden oluşmaktadır. Katılımcıların 72'si 1. Sınıf (\%20,3), 79'u 2. Sınıf (\%22,3), 96'sı $(\% 27,1) 3$. Sinıf ve 107 'si $(\% 30,2) 4$. Sinıf öğrencisidir.

\section{Veri Toplama Araçları}

\section{Empatik Eğilim Ölçeği}

Dökmen (1988) tarafından geliştirilen beşli likert tipindeki Empatik Eğilim Ölçeği, bireyin günlük yaşamda empati kurma potansiyelini ölçmeye çalışan 20 maddeden oluşur. Yapılan faktör analizi sonuçlarına göre, ölçeğin empatik eğilim, benmerkezci eğilim ve sempatik eğilim 
olmak üzere üç alt boyutu belirlenmiştir. Bu araştırmada ölçeğin yalnızca empatik eğilim alt boyutu kullanılmıştır. Empatik eğilim alt boyutunda 9 madde yer almakta olup EEÖ ile empatik eğilim alt boyutu arasında yüksek düzeyde pozitif ilişki $(\mathrm{r}=, 82 ; \mathrm{p}<, 01)$ bulunmaktadır (Kapık1ran 2007). Ölçeğin güvenirlik çalışmasında empatik eğilim alt boyutu açısından madde toplam korelasyonları $\mathrm{r}=43,9-61,7 ; \mathrm{p}<, 01$ ve iç tutarlılık katsayısı $\alpha=73,15$, olarak hesaplanmıştır.

\section{Revize Edilmiş Utangaçlık Ölçeği}

Revize Edilmiş Utangaçlık Ölçeği alan yazında Cheek ve Buss Utangaçlık Ölçeği (Cheek ve Briggs 1990) olarak da bilinir. Utangaçlık Ölçeği 13 maddeden (örn. "sosyal yeterliliğim konusunda kuşkularım var"; "başkalarından herhangi bir konuda bilgi istemek bana zor gelir"; "karşı cinsten kişilerle birlikteyken daha utangaç olurum") oluşur ve beşli likert tipi bir ölçektir. Ölçeğe verilebilecek cevaplar "bana hiç uygun değil"den "bana çok uygun"a doğru bir değişim gösterir. Ölçekten alınan yüksek puanlar tecrübe edilen yüksek düzey utangaçlığa işaret eder. Ölçeğin iç tutarlılık katsayısı $(\alpha=.90)$ yeterli bulunmuştur ve kırkbeş gün arayla yapılmış olan test tekrar test güvenirlik katsayısı da .88 olarak bulunmuştur (Cheek \& Briggs 1990). Ölçeğin Türk kültürüne adaptasyonunu Koydemir ve Demir (2005) tarafından yapılmış ve ölçeğin Türkçe formunun iç tutarlık katsayısını .91 olarak rapor edilmiştir. Ayrıca aynı çalışmada utangaçlık ölçeğinin sosyal kaygı ölçeği ile olan korelasyonunun da .77 olduğu belirtilmiştir.

\section{Olumsuz Değerlendirilme Korkusu Ölçeği Kısa Form}

Olumsuz Değerlendirilme Korkusu Ölçeği (Leary 1983) otuz maddelik orijinal Olumsuz Ddeğerlendirilme Korkusu Ölçeğinin (Watson \& Friend 1969) on iki maddelik kısa formudur. Ölçek başkalarından olumsuz değerlendirme alma ile ilgili endişeyi ölçmek için geliştirilmiştir. ODKÖ-KF oniki maddeden oluşur ve bu maddeler orijinal otuz maddenin içinden seçilen maddelerdir (örn. "Başkalarının beni onaylamayacak olmasından korkarım"; "Biriyle konuşurken, hakkımda ne düşündüğü konusunda kaygılanırım"). Ölçeğin bu kısa formunda cevap format1 beşli likerttir. Ölçekten elde edilebilecek puanlar oniki ile altmış arasında değişmektedir. Olumsuz değerlendirilme korkusu ölçeğinin kısa formunun ölçeğin orijinal formu ile olan korelasyonu oldukça yüksektir (Watson \& Friend 1969, r=.96). Ayrıca ölçeğin iç tutarlık katsayısı .90 ve dört hafta arayla yürütülen test tekrar test korelasyonu .75 olarak tespit edilmiştir (Leary 1983). Ölçeğin Türkçe uyarlama çalışmasında (Koydemir \& Demir 2007) hesaplanan iç tutarlık katsayısı ise .94 olarak rapor edilmiştir.

\section{Sosyal Beceri Ölçeği Kısa Form}

Riggio (1986) tarafından geliştirilen Sosyal Beceri Ölçeğinin orijinal formu genel olarak sosyal yeterliği ve sosyal becerinin altı alt boyutunu ölçmektedir. Ölçekteki maddelere (örn. "Kendimi yabancılara tanıtırken genellikle ilk adımı ben atarım"; "Sosyal olmaktan hoşlanırım"; "Bir grup içinde olduğum zaman konuşacağım şeyleri seçmede güçlük çekiyorum") verilebilecek cevaplar beşli likert tipi ölçekte "hiç benim gibi değil"den "tamamen benim gibi"ye doğru değişim göstermektedir. Ölçeğin orijinal formunun alt ölçeklerinin iç tutarlık katsayıları. 62 ile. 87 arasında, test-tekrar test güvenirliği ise .81 ile .96 arasında değişmektedir. Bu çalışmada ölçeğin 30 maddelik kısa formu (Koydemir, 2006) kullanılmıştır ve genel sosyal yeterlik puanı üzerinden değerlendirme yapılmıştır. Koydemir (2006) çalışmasında sosyal beceri ölçeğinin kısa formunun iç tutarlık katsayısını .70 olarak hesaplandığını belirtmişsir.

\section{Kişisel Bilgi Formu}

Kişisel bilgi formu, araştırma grubunu oluşturan RPD öğrencilerinin kişisel bilgilerini (cinsiyet, sınıf, sivil toplum kuruluşu üyeliği, aylık harçlık ve yaşamlarının çoğunun geçtiği yer) elde et- 
mek için araştırmacılar tarafından geliştirilmiştir.

\section{Verilerin Toplanması ve Analizi}

Araştırma verilerinin toplanmasında kullanılan araçlar katılımcılara Mayıs (2015) ayı içerisinde, ders sırasında dağıtılmış, uygulanmış ve toplanmıştır. Toplanan veriler üzerinde "cinsiyet, STK üyelik durumu, düzenli olarak spor yapma durumu, düzenli olarak sanatla uğraşma durumu" değişkenlerine göre öğrencilerin empatik eğilim, utangaçlık, olumsuz değerlendirilme korkusu ve sosyal beceri düzeylerinin farklılaşma durumunu ortaya koymak amacıyla bağımsız gruplar için t testi, "sınıf, aylık harçlık, yaşamın çoğunun geçtiği yer ve karşı cinsle tanışma yolu tercihi" değişkenlerine göre farklılaşma durumunu ortaya koymak amaciyla tek yönlü varyans analizi (ANOVA) kullanılmıştır. ANOVA testi sonucunda ortaya çıkan farkın kaynağını tespit etmek amacıyla ileri istatistik tekniği olarak TUKEY testi kullanılmıştır. Araştırmada manidarlık düzeyi ,05 olarak alınmıştır.

\section{Bulgular}

RPD öğrencilerinin empatik eğilim, utangaçlık, olumsuz değerlendirilme korkusu ve sosyal beceri düzeylerinin cinsiyetlerine göre farklılaşma durumunu ortaya koymak amacıyla bağımsız gruplar için $\mathrm{t}$ testi analizi yapılmıştır. Yapılan analize ilişkin bulgular Tablo 1'de verilmiştir.

Tablo 1. RPD Öğrencilerinin Empatik Eğilim, Utangaçlık, Olumsuz Değerlendirilme Korkusu ve Sosyal Beceri Düzeylerinin Cinsiyetlerine Göre Farklılaşmasına İlişkin T-Testi Sonuçları

\begin{tabular}{|c|c|c|c|c|c|c|}
\hline Değişken & Cinsiyet & $\mathbf{N}$ & $\mathbf{X}$ & Ss & $\mathbf{t}$ & $\mathbf{p}$ \\
\hline \multirow{2}{*}{ Empatik Eğilim } & Erkek & 87 & 32,5977 & 4,18874 & \multirow[t]{2}{*}{$-2,792 *$} & \multirow[t]{2}{*}{, 006} \\
\hline & Kadın & 267 & 33,9700 & 3,91150 & & \\
\hline \multirow{2}{*}{ Utangaçlık } & Erkek & 87 & 33,1724 & 9,73510 & \multirow[t]{2}{*}{1,181} & \multirow[t]{2}{*}{,238 } \\
\hline & Kadın & 267 & 31,8202 & 9,11732 & & \\
\hline \multirow{2}{*}{$\begin{array}{l}\text { Olumsuz Değerlendirilme } \\
\text { Korkusu }\end{array}$} & Erkek & 87 & 33,5402 & 6,16216 & \multirow[t]{2}{*}{,- 360} & \multirow[t]{2}{*}{, 719} \\
\hline & Kadın & 267 & 33,8052 & 5,27794 & & \\
\hline \multirow{2}{*}{ Sosyal Beceri } & Erkek & 87 & 94,8391 & 10,81867 & \multirow[t]{2}{*}{,- 859} & \multirow[t]{2}{*}{,391 } \\
\hline & Kadın & 267 & 95,9551 & 10,42760 & & \\
\hline
\end{tabular}

Tablo 1 incelendiğinde RPD öğrencilerinin utangaçlık, olumsuz değerlendirilme korkusu ve sosyal beceri düzeyleri arasında cinsiyetlerine göre anlamlı bir farklılık bulunamamıştır. Bununla birlikte empatik eğilim düzeyleri konusunda grupların puan ortalamaları arasındaki farkın anlamlılığını test etmek amacıyla hesaplanan $t$ değeri $(t=-2,792, p<, 05)$ grupların puan ortalamaları arasındaki farkın anlamlı olduğunu ifade etmektedir. Bu bulguya göre, erkek öğrencilerin empatik eğilim düzeyleri kadın öğrencilerin empatik eğilim düzeylerinden anlamlı düzeyde düşüktür. RPD öğrencilerinin empatik eğilim, utangaçlık, olumsuz değerlendirilme korkusu ve sosyal beceri düzeylerinin sınıflarına göre anlamlı düzeyde farklılaşma durumunu ortaya koymak amacıyla tek yönlü varyans analizi (ANOVA) yapılmıştır. Yapılan analize ilişkin bulgular Tablo 2 ve Tablo 3'te verilmiştir. 
Tablo 2. RPD Öğrencilerinin Sınıflarına Göre Empatik Eğilim, Utangaçlık, Olumsuz Değerlendirilme Korkusu ve Sosyal Beceri Düzeyleri Puanlarına İlişkin N, X ve Ss Değerleri

\begin{tabular}{lllll}
\hline Değişken & Sinıf & N & X & Ss \\
\hline \multirow{3}{*}{ Empatik Eğilim } & 1. Sınıf & 72 & 33,4583 & 4,05573 \\
& 2. Sınıf & 79 & 33,2785 & 4,47195 \\
& 3. Sınıf & 96 & 33,6354 & 3,61610 \\
& 4. Sınıf & 107 & 34,0093 & 4,01059 \\
\cline { 2 - 5 } Utangaçlık & 2. Sinıf & 72 & 34,3750 & 10,06799 \\
& 2. Sinıf & 79 & 33,8228 & 9,44995 \\
Olumsuz & 4. Sinıf & 96 & 31,6042 & 8,79052 \\
Değerlendirilme & 107 & 29,9159 & 8,54414 \\
Korkusu & 1. Sinıf & 72 & 35,2083 & 6,42166 \\
& 2. Sinıf & 79 & 34,1266 & 5,31897 \\
& 3. Sinıf & 96 & 32,9063 & 5,25973 \\
Sosyal Beceri & 4. Sinıf & 107 & 33,2150 & 5,00383 \\
\cline { 2 - 5 } & 1. Sinıf & 72 & 94,0833 & 10,80134 \\
& 2. Sinıf & 79 & 96,0886 & 10,40240 \\
\hline & 3. Sinıf & 96 & 94,6458 & 10,25771 \\
\hline
\end{tabular}

Tablo 2 incelendiğinde empatik eğilim düzeyi açısından en yüksek puan ortalamasının 4. Sınıf öğrencilerine ait olduğu, bunu sırasıyla 3. Sınıf, 1. Sınıf ve 2. Sınıf öğrencilerinin izlediği görülmektedir.

Utangaçlık düzeyi açısından en yüksek puan ortalamasının 1. Sınıf öğrencilerine ait olduğu, bunu sırasıyla ile 2. Sınıf, 3. Sınıf ve 4. Sınıf öğrencilerinin izlediği görülmektedir.

Olumsuz değerlendirilme korkusu düzeyi açısından en yüksek puan ortalamasının 1. Sınıf öğrencilerine ait olduğu, bunu sırasıyla 2. Sınıf, 4. Sınıf ve ile 3. Sınıf öğrencilerinin izlediği görülmektedir.

Sosyal beceri düzeyi açısından en yüksek puan ortalamasının 4. Sınıf öğrencilerine ait olduğu, bunu sırasıyla 2. Sınıf, 3. Sınıf ve 1. Sınıf öğrencilerinin izlediği görülmektedir.

Tablo 3. RPD Öğrencilerinin Sınıflarına Göre Empatik Eğilim, Utangaçlık, Olumsuz Değerlendirilme Korkusu ve Sosyal Beceri Düzeylerine İlişkin Varyans Analizi Sonuçları

\begin{tabular}{llllllll}
\hline Değişken & Sınıf & KT & sd & KO & F & p & TUKEY \\
\hline \multirow{2}{*}{ Empatik Eğilim } & Gruplar arası & 27,281 & 3 & 9,094 &, 561 &, 641 & --- \\
& Grup içi & 5674,979 & 350 & 16,214 & & & \\
Utangaçlık & Toplam & 5702,260 & 353 & & & & \\
\cline { 2 - 8 } & Gruplar aras1 & 1140,167 & 3 & 380,056 & $\mathbf{4 , 5 4 9 *}$ & $\mathbf{, 0 0 4}$ & 4.sınıf-1.sınıf \\
\hline
\end{tabular}




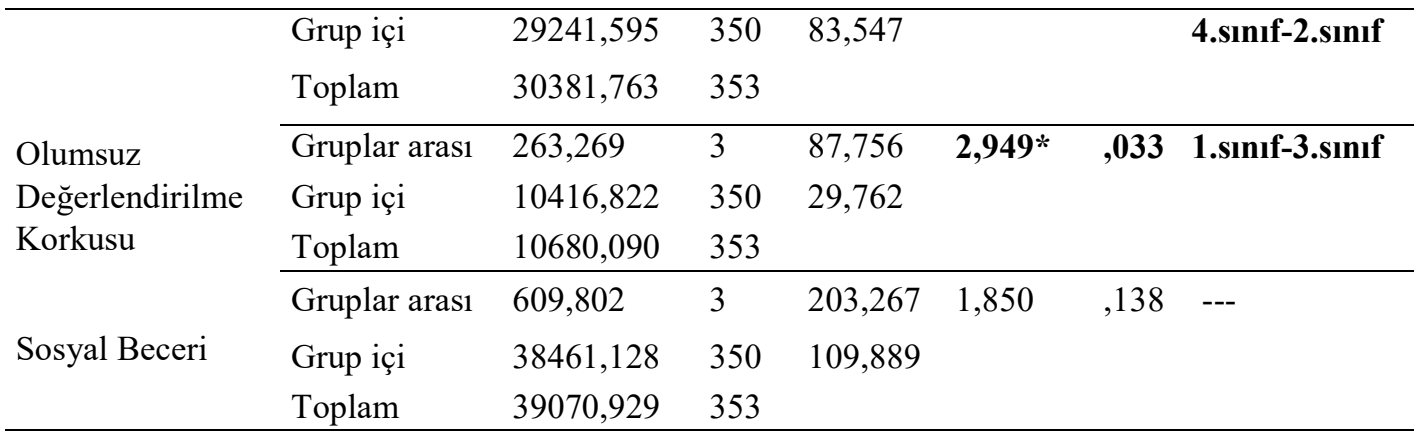

Tablo 3 incelendiğinde RPD öğrencilerinin empatik eğilim ve sosyal beceri düzeyleri arasında sınıflarına göre anlamlı bir farklılık bulunamamıştır. Bununla birlikte utangaçlık düzeyi için hesaplanan $F$ değeri $(F=4,549 ; \mathrm{p}<, 05)$ ve olumsuz değerlendirilme korkusu düzeyi için hesaplanan $\mathrm{F}$ değeri $(\mathrm{F}=2,949 ; \mathrm{p}<, 05)$ incelendiğinde gruplar arasında anlamlı bir farkın olduğu görülmektedir.

Utangaçlık ve olumsuz değerlendirilme korkusu düzeyleri konusunda grupların puan ortalamaları arasındaki farkın kaynağını belirlemek amacıyla yapılan TUKEY testi sonuçlarına göre, RPD öğrencilerinin sınıfları açısından utangaçlık düzeyleri puan ortalamaları arasındaki fark incelendiğinde 4. Sinıfta öğrenim gören öğrenciler ile 1. ve 2. Sınıfta öğrenim gören öğrenciler arasında anlamlı bir farklılaşmanın olduğu Tablo 3'te görülmektedir. Bu bulguya göre 4. Sınıftaki öğrencilerin utangaçlık düzeyleri, 1. ve 2. Sınıfta öğrenim gören öğrencilerin utangaçlık düzeylerinden anlamlı düzeyde düşüktür.

RPD öğrencilerinin sınıfları açısından olumsuz değerlendirilme korkusu düzeyleri puan ortalamaları arasındaki fark incelendiğinde 1. Sinıfta öğrenim gören öğrenciler ile 3. Sınıfta öğrenim gören öğrenciler arasında anlamlı farklılaşmanın olduğu Tablo 3'te görülmektedir. Bu bulguya göre 1. Sınıftaki öğrencilerin olumsuz değerlendirilme korkusu düzeyleri, 3. Sınıfta öğrenim gören öğrencilerin olumsuz değerlendirilme korkusu düzeylerinden anlamlı düzeyde yüksektir.

RPD öğrencilerinin empatik eğilim, utangaçlık, olumsuz değerlendirilme korkusu ve sosyal beceri düzeylerinin STK üyelik durumlarına göre farklılaşma durumunu ortaya koymak amacıyla bağımsız gruplar için t testi analizi yapılmıştır. Yapılan analize ilişkin bulgular Tablo 4'te verilmiştir.

Tablo 4. RPD Öğrencilerinin Empatik Eğilim, Utangaçlık, Olumsuz Değerlendirilme Korkusu ve Sosyal Beceri Düzeylerinin STK Üyelik Durumlarına Göre Farklılaşmasına İlişkin T-Testi Sonuçları

\begin{tabular}{|c|c|c|c|c|c|c|}
\hline Değişken & $\begin{array}{l}\text { STK } \\
\text { Durumu }\end{array}$ & Üyelik $_{N}$ & $\mathbf{X}$ & Ss & $\mathbf{t}$ & p \\
\hline \multirow{2}{*}{ Empatik Eğilim } & Evet & 121 & 34,7273 & 3,54024 & $3,760^{*}$ &, 000 \\
\hline & Hayır & 233 & 33,0644 & 4,14086 & & \\
\hline \multirow{2}{*}{ Utangaçlık } & Evet & 121 & 29,5207 & 8,91170 & $-3,924^{*}$ & ,000 \\
\hline & Hayır & 233 & 33,5193 & 9,18633 & & \\
\hline \multirow{2}{*}{$\begin{array}{l}\text { Olumsuz } \\
\text { Korkusu }\end{array}$} & DeğerlendirilmeEvet & 121 & 33,0826 & 5,85461 & $-1,624$ &, 105 \\
\hline & Hayır & 233 & 34,0815 & 5,28802 & & \\
\hline \multirow{2}{*}{ Sosyal Beceri } & Evet & 121 & 99,7025 & 10,35507 & $5,385 *$ &, 000 \\
\hline & Hayır & 233 & 93,5923 & 10,00652 & & \\
\hline
\end{tabular}


Tablo 4 incelendiğinde, RPD öğrencilerinin olumsuz değerlendirilme korkusu düzeyleri arasında STK üyelik durumlarına göre anlamlı bir farklılık bulunamamıştır. Bununla birlikte empatik eğilim düzeyleri konusunda grupların puan ortalamaları arasındaki farkın anlamlılığını test etmek amacıyla hesaplanan $\mathrm{t}$ değeri $(\mathrm{t}=3,760, \mathrm{p}<, 05)$ grupların puan ortalamaları arasındaki farkın anlamlı olduğunu ifade etmektedir. Bu bulguya göre, STK üyeliği olan öğrencilerin empatik eğilim düzeyleri STK üyeliği olmayan öğrencilerin empatik eğilim düzeylerinden anlamlı düzeyde yüksektir.

RPD öğrencilerinin utangaçlık düzeyleri konusunda grupların puan ortalamaları arasındaki farkın anlamlılığını test etmek amacıyla hesaplanan $t$ değeri $(\mathrm{t}=-3,924, \mathrm{p}<, 05)$ grupların puan ortalamaları arasındaki farkın anlamlı olduğunu ifade etmektedir. Bu bulguya göre STK üyeliği olan öğrencilerin utangaçlık düzeyleri STK üyeliği olmayan öğrencilerin utangaçlık düzeylerinden anlamlı düzeyde düşüktür.

RPD öğrencilerinin sosyal beceri düzeyleri konusunda grupların puan ortalamaları arasındaki farkın anlamlılığını test etmek amacıyla hesaplanan $\mathrm{t}$ değeri $(\mathrm{t}=5,385, \mathrm{p}<, 05)$ grupların puan ortalamaları arasındaki farkın anlamlı olduğunu ifade etmektedir. Bu bulguya göre STK üyeliği olan öğrencilerin sosyal beceri düzeyleri STK üyeliği olmayan öğrencilerin sosyal beceri düzeylerinden anlamlı düzeyde yüksektir.

RPD öğrencilerinin empatik eğilim, utangaçlık, olumsuz değerlendirilme korkusu ve sosyal beceri düzeylerinin aylık harçlıklarına göre anlamlı düzeyde farklılaşma durumunu ortaya koymak amacıyla tek yönlü varyans analizi (ANOVA) yapılmıştır. Yapılan analize ilişkin bulgular Tablo 5 ve Tablo 6'da verilmiştir.

Tablo 5. RPD Öğrencilerinin Aylık Harçlıklarına Göre Empatik Eğilim, Utangaçlık, Olumsuz Değerlendirilme Korkusu ve Sosyal Beceri Düzeyleri Puanlarına İlişkin N, X ve Ss. Değerleri

\begin{tabular}{lllll} 
Değişken & Aylık harçlık & N & X & Ss \\
\hline \multirow{3}{*}{ Empatik Eğilim } & 200 TL'ye kadar & 48 & 33,4375 & 3,78073 \\
& $201-400$ TL & 215 & 33,5116 & 3,92078 \\
& 401 TL ve üzeri & 91 & 34,0220 & 4,37411 \\
\cline { 2 - 5 } 200 TL'ye kadar & 48 & 32,9167 & 9,47973 \\
Utangaçlık & 201-400 TL & 215 & 32,4651 & 9,31773 \\
Olumsuz & 401 TL ve üzeri & 91 & 31,0110 & 9,07438 \\
Değerlendirilme & 200 TL'ye kadar & 48 & 33,8958 & 5,51686 \\
Korkusu & 201-400 TL & 215 & 34,0698 & 5,42750 \\
& 401 TL ve üzeri & 91 & 32,8791 & 5,63094 \\
Sosyal Beceri & 200 TL'ye kadar & 48 & 92,9583 & 9,68868 \\
& 401-400 TL & 215 & 95,4930 & 9,86207 \\
& & 91 & 97,5604 & 12,09243 \\
\hline
\end{tabular}

Tablo 5 incelendiğinde empatik eğilim düzeyi açısından en yüksek puan ortalamasının aylık harçlığı 401 TL ve üzeri olan öğrencilere ait olduğu, bunu sirasiyla 201-400 TL, 200 TL'ye kadar olan öğrencilerin izlediği görülmektedir.

Utangaçlık düzeyi açısından en yüksek puan ortalamasının aylık harçlığı 200 TL’ye kadar 
olan öğrencilere ait olduğu, bunu sırasıyla 201-400 TL, 401 TL ve üzeri olan öğrencilerin izlediği görülmektedir.

Olumsuz değerlendirilme korkusu düzeyi açısından en yüksek puan ortalamasının aylık harçlı̆g 1 201-400 TL olan öğrencilere ait olduğu, bunu sırasıyla 200 TL'ye kadar, 401 TL ve üzeri olan öğrencilerin izlediği görülmektedir.

Sosyal beceri düzeyi açısından en yüksek puan ortalamasının aylık harçlığı 401 TL ve üzeri olan öğrencilere ait olduğu, bunu sirasıyla 201-400 TL, 200 TL'ye kadar olan öğrencilerin izlediği görülmektedir.

RPD öğrencilerinin empatik eğilim, utangaçlık, olumsuz değerlendirilme korkusu ve sosyal beceri düzeylerinin aylık harçlıklarına göre farklılaşmasına ilişkin varyans analizi sonuçları Tablo 6'da verilmiştir.

Tablo 6. RPD Öğrencilerinin Aylık Harçlıklarına Göre Empatik Eğilim, Utangaçlık, Olumsuz Değerlendirilme Korkusu ve Sosyal Beceri Düzeylerine İlişkin Varyans Analizi Sonuçları

\begin{tabular}{llllllll}
\hline Değişken & Aylık harçlık & KT & sd & KO & F & p & TUKEY \\
\hline \multirow{2}{*}{ Empatik Eğilim } & Gruplar arası & 18,770 & 2 & 9,385 &, 580 &, 561 & --- \\
& Grup içi & 5683,489 & 351 & 16,192 & & & \\
& Toplam & 5702,260 & 353 & & & & \\
\cline { 2 - 7 } Utangaçlık & Gruplar arası & 167,619 & 2 & 83,809 &, 974 &, 379 & --- \\
& Grup içi & 30214,144 & 351 & 86,080 & & & \\
Olumsuz & Toplam & 30381,763 & 353 & & & & \\
Değerlendirilme & Gruplar arası & 91,987 & 2 & 45,994 & 1,525 &, 219 & --- \\
Korkusu & Grup içi & 10588,103 & 351 & 30,166 & & & \\
& Toplam & 10680,090 & 353 & & & & \\
Sosyal Beceri & Gruplar arası & 684,856 & 2 & 342,428 & $\mathbf{3 , 1 3 1 *}, \mathbf{0 4 5}$ & $\mathbf{4 0 1}$ TL ve üzeri- \\
& Grup içi & 38386,074 & 351 & 109,362 & & & $\mathbf{2 0 0}$ TL'ye kadar \\
& Toplam & 39070,929 & 353 & & & & \\
\hline
\end{tabular}

Tablo 6 incelendiğinde RPD öğrencilerinin empatik eğilim, utangaçlık ve olumsuz değerlendirilme korkusu düzeyleri arasında aylık harçlıklarına göre anlamlı bir farklılık bulunamamıştır. Bununla birlikte sosyal beceri düzeyi için hesaplanan F değeri $(3,131 ; \mathrm{p}<, 05)$ ilgili konuda gruplar arasında anlamlı bir farkın olduğunu ifade etmektedir.

Sosyal beceri düzeyleri konusunda grupların puan ortalamaları arasındaki farkın kaynağını belirlemek amacıyla yapılan TUKEY testi sonuçlarına göre, RPD öğrencilerinin aylık harçlıkları açısından sosyal beceri puan ortalamaları arasındaki fark incelendiğinde aylık harçlığı 401 TL ve üzeri olan öğrenciler ile 200 TL'ye kadar olan öğrenciler arasında anlamlı bir farklılaşmanın olduğu Tablo 6' da görülmektedir. Bu bulguya göre aylık harçlığı 401 TL ve üzeri olan öğrencilerin sosyal beceri düzeyleri, 200 TL'ye kadar olan öğrencilerin sosyal beceri düzeylerinden anlamlı düzeyde yüksektir.

RPD öğrencilerinin empatik eğilim, utangaçlık, olumsuz değerlendirilme korkusu ve sosyal beceri düzeylerinin yaşamlarının çoğunun geçtiği yere göre anlamlı düzeyde farklılaşma durumunu ortaya koymak amacıyla tek yönlü varyans analizi (ANOVA) yapılmıştır. Yapılan analize ilişkin bulgular Tablo 7 ve Tablo 8'de verilmiştir. 
Tablo 7. RPD Öğrencilerinin Yaşamlarının Çoğunun Geçtiği Yere Göre Empatik Eğilim, Utangaçlık, Olumsuz Değerlendirilme Korkusu ve Sosyal Beceri Düzeyleri Puanlarına İlişkin N, X ve Ss. Değerleri

\begin{tabular}{lllll}
\hline Değişken & $\begin{array}{l}\text { Yaşamın } \\
\text { çoğunun geçtiği yer }\end{array}$ & N & X & Ss \\
& Köy-Kasaba & 49 & 33,3673 & 3,98274 \\
& İlçe & 83 & 32,7711 & 4,48663 \\
Empatik Eğilim & İl & 128 & 33,9922 & 4,04209 \\
& Büyükşehir & 94 & 34,0426 & 3,46694 \\
\cline { 2 - 5 } & Köy-Kasaba & 49 & 33,8367 & 9,15002 \\
Utangaçlık & İlçe & 83 & 34,0843 & 9,45877 \\
& İl & 128 & 31,6094 & 9,29163 \\
& Büyükşehir & 94 & 30,3085 & 8,83301 \\
Olumsuz & Köy-Kasaba & 49 & 34,5510 & 5,55301 \\
Değerlendirilme & İlçe & 83 & 33,2410 & 5,16695 \\
Korkusu & İl & 128 & 34,2813 & 5,70666 \\
& Büyükşehir & 94 & 33,0213 & 5,42392 \\
\hline Kosyal Beceri & Köy-Kasaba & 49 & 94,7959 & 10,56523 \\
& İlçe & 83 & 93,8916 & 11,05420 \\
& İl & 128 & 96,4766 & 10,18178 \\
& Büyükş̧ehir & 94 & 96,6383 & 10,39836 \\
\hline
\end{tabular}

Tablo 7 incelendiğinde empatik eğilim düzeyi açısından en yüksek puan ortalamasının yaşamının çoğu büyükşehirde geçen öğrencilere ait olduğu, bunu sırasıyla ilde, köy-kasabada ve ilçede geçen öğrencilerin izlediği görülmektedir.

Utangaçlık düzeyi açısından en yüksek puan ortalamasının yaşamının çoğu ilçede geçen öğrencilere ait olduğu, bunu sırasıyla köy-kasabada, ilde ve büyükşehirde geçen öğrencilerin izlediği görülmektedir.

Olumsuz değerlendirilme korkusu düzeyi açısından en yüksek puan ortalamasının yaşamının çoğu köy-kasabada geçen öğrencilere ait olduğu, bunu sırasıyla ilde, ilçede ve büyükşehirde geçen öğrencilerin izlediği görülmektedir.

Sosyal beceri düzeyi açısından en yüksek puan ortalamasının yaşamının çoğu büyükşehirde geçen öğrencilere ait olduğu, bunu sırasıyla ilde, köy-kasabada ve ilçede geçen öğrencilerin izlediği görülmektedir.

RPD öğrencilerinin yaşamlarının çoğunun geçtiği yere göre empatik eğilim, utangaçlık, olumsuz değerlendirilme korkusu ve sosyal beceri düzeylerinin farklılaşmasına ilişkin varyans analizi sonuçları Tablo 8'de verilmiş̧tir. 
Tablo 8. RPD Öğrencilerinin Yaşamlarının Çoğunun Geçtiği Yere Göre Empatik Eğilim, Utangaçlık, Olumsuz Değerlendirilme Korkusu ve Sosyal Beceri Düzeylerine İlişkin Varyans Analizi Sonuçları

\begin{tabular}{|c|c|c|c|c|c|c|c|}
\hline Değiş̧ken & $\begin{array}{l}\text { Yaşamın } \\
\text { çoğunun } \\
\text { geçtiği yer }\end{array}$ & KT & sd & KO & $\mathbf{F}$ & $\mathbf{p}$ & TUKEY \\
\hline \multirow{3}{*}{ Empatik Eğilim } & Gruplar aras1 & 97,400 & 3 & 32,467 & 2,027 & , 110 & --- \\
\hline & Grup içi & 5604,860 & 350 & 16,014 & & & \\
\hline & Toplam & 5702,260 & 353 & & & & \\
\hline \multirow{3}{*}{ Utangaçlık } & Gruplar aras1 & 806,137 & 3 & 268,712 & 3,180 * & ,024 & İlçe- \\
\hline & Grup içi & 29575,625 & 350 & 84,502 & & & Büyükşehir \\
\hline & Toplam & 30381,763 & 353 & & & & \\
\hline \multirow{3}{*}{$\begin{array}{l}\text { Olumsuz } \\
\text { Değerlendirilme } \\
\text { Korkusu }\end{array}$} & Gruplar aras1 & 138,955 & 3 & 46,318 & 1,538 & 204 & --- \\
\hline & Grup içi & 10541,136 & 350 & 30,118 & & & \\
\hline & Toplam & 10680,090 & 353 & & & & \\
\hline \multirow{3}{*}{ Sosyal Beceri } & Gruplar aras 1 & 471,314 & 3 & 157,105 & 1,425 & ,235 & --- \\
\hline & Grup içi & 38599,615 & 350 & 110,285 & & & \\
\hline & Toplam & 39070,929 & 353 & & & & \\
\hline
\end{tabular}

Tablo 8 incelendiğinde RPD öğrencilerinin empatik eğilim, olumsuz değerlendirilme korkusu ve sosyal beceri düzeyleri arasında yaşamlarının çoğunun geçtiği göre anlamlı bir farklılık bulunamamıştır. Bununla birlikte utangaçlık düzeyi için hesaplanan $F$ değeri $(F=3,180 ; p<, 05)$, ilgili konuda gruplar arasında anlamlı bir farkın olduğunu ifade etmektedir.

Utangaçlık düzeyleri konusunda grupların puan ortalamaları arasındaki farkın kaynağını belirlemek amacıyla yapılan TUKEY testi sonuçlarına göre RPD öğrencilerinin yaşamının çoğunun geçtiği yer açısından utangaçlık puan ortalamaları arasındaki fark incelendiğinde yaşamının çoğu ilçede geçen öğrenciler ile büyükşehirde geçen öğrenciler arasında anlamlı bir farklılaşmanın olduğu Tablo 10'da görülmektedir. Bu bulguya göre yaşamının çoğu ilçede geçen öğrencilerin utangaçlık düzeyleri, büyükşehirde geçen öğrencilerin utangaçlık düzeylerinden anlamlı düzeyde yüksektir.

\section{Sonuç, Tartışma ve Öneriler}

Bu çalışmada Erciyes Üniversitesi RPD lisans programı öğrencilerinin empatik eğilim, utangaçlık, olumsuz değerlendirilme korkusu ve sosyal beceri düzeylerinin cinsiyet, sınıf, aylık harçlık, yaşamın çoğunun geçtiği yer ve STK üyelik durumu değişkenlerine göre farklılaşma düzeyleri incelenmiştir. Araştırma bulguları 2014-2015 yıllarında Kayseri Erciyes Üniversitesi RPD programında öğrenim gören gönüllü öğrencilerden elde edilen bulgulara dayanır ve araştırmanın değişkenleri Empatik Eğilim Ölçeği, Utangaçlık Ölçeği, Olumsuz Değerlendirilme Korkusu Ölçeği ve Sosyal Beceri Ölçeğinin ölçtüğü niteliklerle sınırlıdır.

Çalışmaya katılan erkek öğrencilerin empatik eğilim düzeyi kadın öğrencilerin empatik eğilim düzeyinden anlamlı düzeyde düşük çıkmıştır. Bu bulgu kadınların duyguları anlama ve ona göre tepki verme konusunda erkeklere göre daha başarılı olduğuna dair alan yazındaki pek çok araştırma ile paralellik gösterir (örn. McDevitt, Lennon \& Kopriva 1991; Rees \& Sheard 2002; Hojat et al. 2002; Harlak et al. 2008; Kapıkıran 2009; Akbulut \& Sağlam 2010; Kapıkıran, Kapıkıran \& 
Başaran 2010).

Sınıflara göre empatik eğilim düzeylerinin farklılaşması incelendiğinde sınıflar arasında anlamlı bir farklılık bulunamamıştır. Bu bulgu alan yazındaki bazı çalışmalarla (Ünal 1997; Güler \& Gazioğlu 2008) benzerlik gösterse de empatik beceri ile ilgili olarak yürütülmüş bazı çalışmalarla uyuşmamaktadır (Yıldırım 1992; Karataş 2012). Örneğin Yıldırım (1992) RPD ve Psikoloji 4. sınıf öğrencilerinin empatik beceri düzeyinin RPD 1. sınıf ve Psikoloji 1. sınıf öğrencilerininkinden yüksek olduğunu bulmuştur. Yine Karaca, Açıkgöz ve Akkuş (2013) çalışmalarında, empatik beceri geliştirme programı ile hemşirelik birinci sınıf öğrencilerinin empatik becerilerinin önemli oranda arttığı; ancak empatik eğilimlerinde değişiklik olmadığ sonucunu ortaya koymuştur. Empatik Eğilim ölçeğini geliştiren Dökmen'in (1988) RPD 1. sınıf öğrencilerine Psikodrama eğitimi vermek suretiyle yürüttüğü çalışmada ise eğitim sonunda empatik becerinin arttığını ancak empatik eğilim düzeyinde bir değişiklik olmadığı ortaya çıkmıştır ve buradan hareketle empatik eğilimin empatik beceriden farklı bir kişilik özelliği olarak ele alınması gerektiği vurgulanmıştır. Ancak empatik eğilimin verilen eğitimle artmadığını gösteren bu bulguların aksine, Harlak ve arkadaşlarının (2008) empatik eğilim ile ilgili olarak yapıtıkları bir diğer deneysel çalışmada, öğrenciler düşük ve yüksek empati grubu olarak ikiye ayırılmış daha sonra ise bir beceri eğitiminden geçmişlerdir ve sonuçlar düşük empati grubundaki öğrencilerin otuz saatlik sosyal beceri eğitimi sonrasında empatik eğilimlerinin anlamlı derecede arttığını, yüksek empati grubundaki öğrencilerin empatik eğilim düzeylerinde ise anlamlı bir değişiklik olmadığını göstermiştir.

Çalışmada elde edilen bir diğer bulguya göre, STK üyeliği olan öğrencilerin empatik eğilim düzeyleri STK üyeliği olmayan öğrencilerin empatik eğilim düzeylerinden anlamlı derecede yüksek çıkmıştır. Bu bulgu, sivil toplum kuruluşlarına üye olan ve çeşitli sosyal faaliyetlerde bulunan öğrencilerin empatik eğilimlerinin yüksek olduğunu göstermiştir. Kouliou, Dragioti, Kotrotsiou ve Gouva (2012), sivil toplum örgütlerinde gönüllü olarak çalışan kişilerin kişilik özelliklerini araştırdıkları araştırmada gönüllülerle gönüllü olmayan kişilerin empatiye benzer bir kavram olan alturizm (özgecilik) açısından oldukça farklılaştığını bulmuşlardır.

Utangaçlık düzeyi ve sınıf değişkeni incelendiğinde 4. sınıfta öğrenim gören öğrencilerin utangaçlık düzeyleri, 1 . ve 2. sinıfta öğrenim gören öğrencilerin utangaçlık düzeyinden anlamlı düzeyde düşük olduğu göze çarpmaktadır. Bu bulgu bizlere RPD programında bulunan bazı derslerin (Sosyal Beceri, Kişilerarası İletişim, Evlilik ve Aile, Cinsel Sağlık Eğitimi vb.) ve öğrencinin üniversitede geçirdiği yıllarda yaşadıklarının etkisi ile bir miktar daha utangaçlıktan sıyrıldığını gösterebilir. Meslek hayatında pek çok farklı kişi, durum ve sorun ile karşılaşacak olan Psikolojik Danışmanların eğitimleri sırasında bu özelliklerinin bir miktar azalmasının gelecekteki mesleki yaşantıları için faydalı olacağı düşünülmektedir.

STK üyeliği olan öğrencilerin utangaçlık düzeyleri STK üyeliği olmayanlara göre anlamlı düzeyde düşüktür. Literatürde sıkça tekrarlanan girişkenlik becerilerinin utangaçlıkla olan negatif yönlü ilişkisi bu bulguyu desteklemektedir. Handy ve Cnaan (2007) utangaçlığın ve sosyal kaygının gönüllülük için başvuruda bulunmayı etkilediğini belirtmişlerdir. Benzer olarak, Stravynski ve Amado (2001) sosyal kaygısı olan kişilerin düşüncelerini ve duygularını kaygı veren bir sosyal etkileşim içerisinde nadiren paylaştıklarını belirtmiştir. Yashima (2010) ise yürüttüğü çalışmada uluslarası gönüllü çalışmalara ilk defa katılan katılımcıların kendilerini ifade etme noktasında kaygı ve utangaçlık düzeylerinde bir azalma olduğunu belirtmiştir.

Çalışmamızın bir diğer bulgusu, yaşamlarının çoğu ilçede geçen öğrencilerin utangaçlık düzeylerinin, yaşamlarının çoğu büyükşehirde geçen öğrencilerin utangaçlık düzeylerinden anlamlı düzeyde yüksek çıkmış olmasıdır. $\mathrm{Bu}$ bulgu literatürle paralellik göstermektedir. 
Örneğin, Erol ve Avcı-Temizer (2015) çalışmalarında lise öğrencilerin utangaçlık düzeylerinin, yaşamın çoğunun geçirildiği yerleşim yeri değişkenine göre anlamlı düzeyde farklılık gösterdiğini belirtmişlerdir. Yine Altıok (2011) çalışmasında öğrencilerin yaşadığı yere göre utangaçlık puanının önemli düzeyde farklılık gösterdiği sonucuna varmıştır. Erdal (2003) ise araştırmasında büyükşehirde yaşayan kadınların utangaçlık düzeylerinin küçük şehirlerde yaşayanların utangaçlık düzeyine göre daha düşük olduğunu saptamıştır. Bu bulgu yaşamının büyük bölümünü kasaba ve köyde geçiren bireylerin, yaşamının büyük bölümünü şehirde ve ilçede geçiren bireylere göre düşük düzeyde öz saygıya ve atılganlığa sahip olduğu bulgularıyla da (Y1lmaz \& Ekinci 2001; Kahriman 2005; Dinçer \& Öztunç 2009) paralellik göstermektedir. Alan yazındaki bazı çalışmalar ise yaşanılan yer ve utangaçlık değişkeni arasında anlamlı bir ilişki bulunmadığını belirtmişlerdir (Cabak 2002; Kanak \& Pekdoğan 2015).

Olumsuz değerlendirilme korkusu ve sınıf ilişkisine bakıldığında ise 1. sınıftaki öğrencilerin olumsuz değerlendirilme korkusu düzeylerinin, 3. sınıfta öğrenim gören öğrencilerin olumsuz değerlendirilme korkusu düzeylerinden anlamlı düzeyde yüksek olduğu bulunmuştur. Aydın (2008) İngilizce öğretmenliği bölümünde yürüttüğü araştırmasında sınıf seviyesi arttıkça olumsuz değerlendirilme korkusunun azaldığını belirtmiştir. Bu bulgu, üniversiteye yeni başlayan 1. sınıftaki öğrencilerin yaşadığ 1 çeşitli kaygılar düşünüldüğünde kolaylıkla anlaşılabilir. Üçüncü sınıfta öğrenciler üniversiteye ilk geldiklerinde yaşadıkları acemilik dönemini artık yaşamadıkları gibi pek çok anlamda üniversite hayatına, derslere, arkadaşlarına ve hocalarına alışmışlardır ve artık nereden nasıl bir değerlendirme alacaklarını rahatlıkla tahmin edebilmektedirler, dolayısıyla bu tür bir kaygı duymaları beklenmemektedir. Birinci ve üçüncü sınıflar arasında çıkan bu farkın 1. ve 4. sınıflar arasında çıkmamasını da 4. sınıfların yaklaşan KPSS sınavı ve mezuniyet ile ilgili kaygı ve korkularıyla açıklamak oldukça anlamlı görünmektedir.

Sosyal beceri düzeyi ve STK üyeliği arasındaki ilişkiye bakıldığında STK üyeliği olan öğrencilerin sosyal beceri düzeylerinin STK üyeliği olmayan öğrencilerin sosyal beceri düzeylerinden anlamlı düzeyde yüksek olduğu bulunmuştur. STK'larda faaliyette bulunmanın öğrencilerin algıladıkları sosyal becerileri üzerinde olumlu bir etkisinin olması beklendik bir durumdur. Zira sosyal beceri eğitim modülleri de bu tür gönüllü çalışmaları becerileri test etmek için sürekli olarak teşvik etmektedir.

Araştırmanın bir diğer bulgusu ise aylık harçlık ile ilgilidir, aylık harçlığı 401 TL ve üzeri olan öğrencilerin sosyal beceri düzeyleri, aylık harçlığ 200 TL'ye kadar olan öğrencilerin sosyal beceri düzeylerinden anlamlı düzeyde yüksek bulunmuştur. Gelir seviyesinin öğrencilerin sosyalleşmesi üzerinde bir etkisinin olduğu kaçınılmaz bir gerçektir. Sosyal faaliyetlerin bir kısmının (sinema, tiyatro, konser, kafede oturma vb.) maliyetlerinin yüksek olması harçlığ1 düşük olan öğrencilerin sosyal becerilerinin gelişmesi üzerinde olumsuz bir etkiye sahip olabilir.

Araştırma sonuçlarından hareketle bazı önerilerde bulunmak mümkündür. Erkek RPD öğrencilerinin empatik eğilim düzeylerini arttırmak için bazı ders içi ve ders dışı programlar geliştirilebilir. Örneğin erkek öğrencilere yönelik sosyal beceri grupları oluşturulabilir. Küçük sınıfların utangaçlık ve olumsuz değerlendirilme korkusunu büyük sınıflara kıyasla daha fazla hissetmelerinden hareketle oryantasyon programlarının sene boyunca devam edecek şekilde planlanması önerilebilir. Aynı şekilde birinci ve ikinci sınıflara yönelik olarak kendilerini rahatça ifade edip sosyal becerilerini arttırırken ve sosyal kaygılarını azaltacak bazı akademik ve sosyal faaliyetlerin (eğitim, çalıştay, seminer, sosyal kulüp, STK vb.) yürütülmesi önerilebilir. $\mathrm{Bu}$ öneri çalışmadan elde edilen bir diğer bulgu ile de örtüşmektedir, nitekim STK üyeliği olan öğrencilerin STK üyeliği olmayan öğrencilere göre empatik eğilimlerinin ve sosyal becerilerinin yüksek, utangaçlıklarının ise düşük çıktığı görülmüştür. 
Daha önce de belirtildiği gibi bu araştırma, boylamsal şekilde planlanan bir araştırmanın ön çalışması niteliğindedir. Araştırma sonucunda elde edilen bulgular, konunun önem düzeyini ortaya koymakta ve RPD programının farklı psikolojik yapıları geliştirme konusundaki etkisini vurgulamaktadır. Bu çalışmanın yanında ilerleyen yıllarda, boylamsal olarak planlanan çalışmanın sunacağı verilerin alan yazına ve psikolojik danışman eğitimine katkı sağlayacağına inanılmaktadır.

\section{KAYNAKÇA}

Akbulut E., \& Sağlam H. İ. (2002). "Sınıf Öğretmenlerinin Empatik Eğilim Düzeylerinin İncelenmesi”. Uluslararasi İnsan Bilimleri Dergisi 7/2 (2002) 1069-1083.

Allen T.W. (1967). "Effectiveness of Counsellor Trainees as a Function of Psychological Openness". Journal of Counseling Psychology 14/1 (1967) 35-40.

Altıok S. (2011). Üniversite Öğrencilerinin Utangaçlık ve Başa Çıkma Stratejileri İlişkilerinin İncelenmesi. Yayımlanmamış Yüksek Lisans Tezi. Osmangazi Üniversitesi, Sağlık Bilimleri Enstitüsü, Eskişehir 2011.

Aydın S. (2008). "An Investigation on the Language Anxiety and Fear of Negative Evaluation Among Turkish EFL Learners". Asian EFL Journal. Teaching Articles (2008) 421-444.

Barrett-Lennard G. T. (1993). "The Phases and Focus of Empathy”. British Journal of Medical Psychology 66 (1993) 3-14.

Beck A. T., Emery G. \& Greenberg L. (1985). Anxiety and Phobias: A Cognitive Perspective. New York 1985.

Briggs S. R. (1988). "Shyness: Introversion or Neuroticism". Journal of Research in Personality 22 (1988) 290-307.

Bruch M. A., Rivet K. M., Heimberg R. G. \& Levin M. A. (1997). "Shyness, Alcohol Expectancies, and Drinking Behavior: Replication and Extension of a Suppressor Effect". Personality and Individual Differences 22 (1997) 193-200.

Caba H. (2002). Lise Öğrencilerinin Utangaçlık Düzeylerinin İncelenmesi. Yayımlanmamış Yüksek Lisans Tezi. İnönü Üniversitesi, Sosyal Bilimler Enstitüsü, Malatya 2002.

Carkhuff R. R. (1969). Helping and Human Relations: A Premier for Lay and Proffesional Helpers. New York 1969.

Cheek J. M. \& Briggs S. R. (1990). "Shyness as a Personality Trait". Ed. W. R. Crozier, Shyness and Embarrassment: Perspectives from Social Psychology (1990) 315-337. Cambridge, UK.

Corey G. (2008). Psikolojik Danışma, Psikoterapi Kuram ve Uygulamaları. Çev. T. Ergene. Ankara 2008.

Cowden C. R. (2005). "Worry and its Relationship to Shyness". North American Journal of Psychology 7 (2005) 59-70.

Curran J. P. (1977). "Skills Training as an Approach to the Treatment of Heterosexualsocial Anxiety". Psychological Bulletin 84 (1977) 140-157.

Davis C. M. (1990). "What is Empathy, and Can it Be Taught?". Physical Theraphy 70 (1990) 707-711.

Dill J. C. \& Anderson C. A. (1999). "Loneliness, Shyness, and Depression: The Etiology and İnterrelationships of Everyday Problems in Living". Eds. T. Joiner \& J. C. Coyne, The Interactional Nature of Depression: Advances in Interpersonal Approaches (1999) 93-125. Washington.

Dinçer F. \& Öztunç G. (2009). "Hemşirelik ve Ebelik Öğrencilerinin Benlik Saygısı ve Atılganlık Düzeyleri”. Sağlık Bilimleri Fakültesi Hemşirelik Dergisi (2009) 22-33.

Doğan S. (2016). Ege Üniversitesi Eğitim Fakültesi Eğitim Bilimleri Bölümü Rehberlik ve Psikolojik Danışmanlık Anabilim Dalı'nın RPD Lisans Programı'nın Güncellenmesine İlişkin Görüşü.

Dökmen Ü. (1988). "Empatinin Bir Modele Dayandırılarak Ölçülmesi ve Psikodrama ile Geliştirilmesi”. 
A. ̈̈. Ĕ̌itim Bilimleri Fakültesi Dergisi 6 (1988) 155-190.

Dökmen Ü. (1994). İletişim Çatışmaları ve Empati. İstanbul 1994.

Egbochuku E. O. (2008). "Counselling Communication Skills: Its Place in the Training Programme of a Counselling Psychologist”. Edo Journal of Counselling 1/1 (2008) 17-32.

Erdal H. (2003). Çalışan ve Çalışmayan Kadınların Utangaçlıklarının Bazı Değişkenler Açısından Incelenmesi. Yayımlanmamış Yüksek Lisans Tezi. Hacettepe Üniversitesi, Sosyal Bilimler Enstitüsü, Ankara 2003.

Erol M. \& Avc1-Temizer D. (2015). "Ergenlerin Utangaçlık Düzeylerinin İncelenmesi”. Türk Psikolojik Danışma ve Rehberlik Dergisi 5/44 (2015) 97-108.

Eysenck H. J. (1952). “The Effects of Psychotherapy: An Evaluation”. Journal of Consulting Psychology 16 (1952) 319-324.

Handy F. \& Cnaan R. A. (2007). "The Role of Social Anxiety in Volunteering”. Nonprofit Management \& Leadership 18/1 (2007) 41-58.

Harlak H., Gemalmaz A., Gürel F. S., Dereboy C. \& Ertekin K. (2008). “Communication Skill training: Effects on Attitudes Toward Communication Skills and Empathic Tendency”. Education for Health 21/2 (2008).

Hill C. E. \& O’Brien K. M. (1999). Helping Skills. Washington 1999.

Hojat M., Gonnella J .S., Mangione S., Nasca T. J., Veloski J. J., Erdmann J. B. et al. (2002). "Empathy in Medical Students as Related to Academic Performance, Clinical Competence and Gender". Medical Education 36 (2002) 522-527.

Hojat M., Mangione S., Nasca T. J., Rattner S., Erdmann J. B., Gonnella J. S. et al. (2004).” An Empirical Study of Decline in Empathy in Medical School”. Medical Education 38 (2004) 934-41.

Jacobs L. (1996). "Shame in the Therapeutic Dialogue". Eds. R. G. Lee \& G. Wheeler, The Voice of Shame: Silence and Connection in Psychotherapy (1996). San Francisco.

Kahriman İ. (2005). "Karadeniz Teknik Üniversitesi Trabzon Sağlık Yüksekokulu Öğrencilerinin Benlik Saygıları ve Atılganlık Düzeylerinin Bazı Değişkenler Açısından İncelenmesi”. C.Ü. Hemşirelik Yüksekokulu Dergisi 9/1 (2005) 24-32

Kanak M. \& Pekdoğan S. (2015). "Ergenlerin Utangaçlık Düzeylerinin Anne-Baba Tutumları ve Bazı Değişkenler Açısından İncelenmesi”. The Journal of Academic Social Science Studies 32/3 (2015) 523-525.

Kapıkıran A. N. (2009). “Öğretmen Adaylarının Empatik Eğilim ve Kendini Ayarlama Açısından İncelenmesi”. Pamukkale Üniversitesi Eğitim Fakültesi Dergisi 26 (2009) 81-91.

Kapıkıran N. A., Kapıkıran Ş. \& Başaran B. I. (2010). "Psikolojik Danışma Ve Rehberlik Öğrencilerinin Empatik Eğilimler ve Algıladıkları Anne Baba Olumlu Sosyal Davranışları: Cinsiyetin Farklılaştırıcı Rolü”. Ege Eğitim Dergisi 11/1 (2010) 1-19.

Karaca A., Açıkgöz F. \& Akkuş D. (2013). "Eğitim ile Empatik Beceriler Geliştirirlebilir Mi? Bir Sağlık Yüksekokulu Örneği”. Acıbadem Üniversitesi Sağlık Bilimleri Dergisi 4/3 (2013) 118-122.

Karataş Z. (2012). "Eğitim Fakültesi Öğrencilerinin Empatik Becerileri ve Benlik Saygısı Düzeylerinin İncelenmesi”. Mehmet Akif Ersoy Üniversitesi Ĕ̈itim Fakültesi Dergisi 23 (2012) 97-114.

Kaufman G. (1993) The Psychology of Shame: Theory and Treatment of Shame Based Syndromes. London 1993.

Kouliou F., Dragioti E., Kotrotsiou E. \& Gouva M. (2012). “A Quantitative Investigation of Personality and Psychological Characteristics on Vulunteers in the Humanitarian non Government Organizations". Interscientific Health Care 4/1 (2012) 34-42.

Koydemir S. \& Demir A. (2007). "Psychometric properties of the brief version of the Fear of Negative Evaluation Scale". Psychological Reports 100 (2007) 883-893.

Koydemir S. (2006). Predictors of Shyness Among University Students: Testing a Self-Presentational Model. Unpublished Doctoral Dissertation. Middle East Technical University, Ankara 2006.

Koydemir S. \& Demir A. (2005). Reliability and Validity of 13-item Cheek and Buss Shyness Scale. Unpublished Manuscript.

Leary M. R. (1983c). “A Brief Version of the Fear of Negative Evaluation Scale”. Personality and Social 
Psychology Bulletin 9 (1983) 371-376.

McDevitt T. M., Lennon R. \& Kopriva R. J. (1991). “Adolescents' Perceptions of Mothers' and Fathers' Prosocial Actions and Empathic Responses". Youth and Society 22/3 (1991) 387-409.

Miville M. L., Carlozzi A. F., Gushue G.V., Schara S. L. \& M. Ueda (2006). "Mental Health Counsellor Qualities for a Diverse Clientele: Linking Empathy, Universal-Diverse Orientation, and Emotional Intelligence". Journal of Mental Health Counseling 28 (2006) 151-165

Pence G. (1983). “Can Compassion Be Taught?”. Journal of Medical Ethics 9 (1983) 189-191.

Pişkin M. (1989). "Empati, Kaygı ve Çatışma Eğilimi Arasındaki İlişki”. Ankara Üniversitesi Eğitim Bilimleri Fakültesi Dergisi 22/2 (1989) 775-784.

Rees C. \& Sheard C. (2002). "The Relationship Between Medical Students' Attitudes Towards Communication Skills Learning and Their Demographic and Education-Related Characteristics". Medical Education 36 (2002) 1017-1027.

Riggio R. (1986). “Assessment of Basic Social Skills”. Journal of Personality and Social Psychology 51 (1986) 649-660.

Riggio R. E., Tucker J. \& Coffaro D. (1989). "Social Skills and Empathy”. Personality and Individual Differences 10/1 (1989) 93-99.

Rogers C. R. (1951). Client Centred Therapy. London 1951.

Rogers C. R. (1957). "The Necessary and Sufficient Conditions of Therapeutic Personality Change". Journal of Consulting Psychology 21 (1957) 95-103

Russell D., Cutrona C. E. \& Jones W. H. (1986). “A Trait-Situational Analysis of Shyness”. Eds. W. H. Jones, J. M. Cheek \& S. R. Briggs, Shyness: Perspectives on Research and Treatment (1986) 239249. New York.

Schlenker B. R. \& Leary M. R. (1982). "Social Anxiety and Self-Presentation: A Conceptualization and Model”. Psychological Bulletin 92 (1982) 641-669.

Schmidt J. J. (2004). A Survival Guide for the Elementary/Middle School Counselor. San Francisco 2004.

Sprinthw N., Whiteley J. \& Mosher R. (1966). “Cognitive Complexity: A Focus for Research on Counselor Effectiveness". Counselor Education and Supervision 5 (1966) 188-197.

Stein E. $\left(1970^{2}\right)$. On the Problem of Empathy. The Hague 1970.

Stravynski A. \& Amado D. (2001). "Social Phobia as a Deficit in Social Skills". Eds. S. G. Hofmann \& P. M. DiBartolo, From Social Anxiety to Social Phobia: Multiple Perspectives (2011) 107-129). Boston.

Ünal G. (1997). Psikolojik Danışma ve Rehberlik Eğitimi Alan Öğrencilerin Empatik Ĕ̆ilimlerinde Gözlenen Değişimler. Yayımlanmamış Yüksek Lisans Tezi. Selçuk Üniversitesi, Sosyal Bilimler Fakültesi, Konya 1997.

Watson A. K. \& Cheek J. M. (1986). "Shyness Situations: Perspectives of a Diversesample of Shy Females". Psychological Reports 59 (1986) 1040-1042.

Watson D. \& Friend R. (1969). "Measurement of Social-Evaluative Anxiety". Journal of Consulting and Clinical Psychology 33/4 (1969) 448-457.

Yashima T. (2010). "The Effects of International Volunteer Work Experiences on Intercultural Competence of Japanese Youth". International Journal of Intercultural Relations 34/3 (2010) 268-282.

Yavuz-Güler Ç. \& İşmen-Gazioğlu A. S. (2008). "Rehberlik ve Psikolojik Danışmanlık Öğrencilerinde Öznel İyi Olma Hali, Psikiyatrik Belirtiler ve Bazı Kişilik Özellikleri: Karşılaştırmalı Bir Çalışma”. Dokuz Eylül Üniversitesi Buca Eğitim Fakültesi Dergisi 23 (2008) 107-114.

Yeşilyaprak B. (2009). “Türkiye'de Psikolojik Danışma ve Rehberlik Alanının Geleceği: Yeni Açılımlar ve Öngörüler”. Ankara Üniversitesi Ĕgitim Bilimleri Fakültesi Dergisi 42/1 (2009) 193-213.

Yıldırım İ. (1992). "Psikolojik Danışma ve Rehberlik Programı Öğrencileri ile Psikoloji Programı Öğrencilerinin Empatik Eğilim ve Empatik Beceri Düzeyleri”. H.Ü. Eğitim Fakültesi Dergisi 7 (1992) 193-208.

Yılmaz S. V. \& Ekinci M. (2001). "Hemşirelik Yüksekokulu Öğrencilerinde Benlik Saygısı ve Atılganlık Düzeyi Arasındaki İlişki”. Atatürk Üniversitesi Hemşirelik Yüksekokulu Dergisi 4/2 (2001) 1-10. 